\title{
Use of trauma scoring systems to determine the physician's responsibility in cases of traumatic death with medical malpractice claim
}

\author{
Murat Nihat Arslan, M.D., ${ }^{1}$ Çisem Kertmen, M.D., ${ }^{2}$ Deniz Oğuzhan Melez, M.D., ${ }^{1}$ \\ Durmuş Evcüman, M.D., ${ }^{3}$ Yalçın Büyük, M.D. ${ }^{4}$
}

\author{
${ }^{1}$ Morgue Department, the Council of Forensic Medicine, İstanbul-Turkey \\ ${ }^{2}$ Düzce Branch Office, the Council of Forensic Medicine, Düzce-Turkey \\ ${ }^{3}$ Çanakkale Branch Office, the Council of Forensic Medicine, Çanakkale-Turkey \\ ${ }^{4}$ The Council of Forensic Medicine, İstanbul-Turkey
}

\begin{abstract}
BACKGROUND: Traumatic injury is near the top of World Health Organization list of leading causes of death, and one of the major factors affecting mortality is the severity of the trauma. During medical intervention for trauma patients, some injuries may be overlooked, and this misstep may be the basis of a malpractice claim. The objective of this study was to provide a new approach to evaluating medical malpractice cases by discussing the benefits of the use of trauma scores.
\end{abstract}

METHODS: Cases of alleged malpractice that were discussed and concluded between 2010 and 2013 were selected from the case archive of the General Committee of the Council of Forensic Medicine (GC of CFM). Injury severity scores were calculated from the medical records of accused physicians and from the autopsy or final clinical evaluation records and compared.

RESULTS: Between the years 2010 and 2013, 263 cases of alleged medical malpractice were discussed and concluded by the general committee. Of these, in 25 cases of patient death, the reason for admission to the hospital was traumatic injury. Various surgical specialties were involved. In these 25 cases, 34 physicians were accused of medical malpractice, and the General Committee classified the interventions of 14 physicians in 12 cases as "malpractice." Missed injuries and unrecognized diagnoses can be established by comparing the Injury Severity Score and New Injury Severity Score values in the findings of accused physicians with the subsequent findings of last evaluation or autopsy.

CONCLUSION: In a medical malpractice case, calculating injury severity scores may assist an expert witness or judge to detect any unseen injuries and to determine the likely survival potential of the patient, but these values do not provide enough information to evaluate all of the evidence or draw conclusions about the entire case. All contributing factors to trauma severity should be considered along with the trauma score and other case factors.

Keywords: Injury Severity Score; medical malpractice; missed injuries; New Injury Severity Score, traumatic deaths.

\section{INTRODUCTION}

In trauma cases resulting in patient death, determination of the cause of death and the causation of death with the

Address for correspondence: Murat Nihat Arslan, M.D.

Çobançeşme Mahallesi, Kımız Sokak., No: I, Bahçelievler, 34196 İstanbul, Turkey

Tel: +90 212 - 4541500 E-mail: mnarslan@yahoo.com

Submitted: 24.08 .2016

Accepted: 06.12.2016

Ulus Travma Acil Cerrahi Derg

2017;23(4):328-336

doi: $10.5505 /$ tjtes.2016.50540

Copyright 2017

TJTES claimed intervention is important in determining any level of physician responsibility in the death (as well as responsibility of the perpetrator, in cases of trauma caused by criminal action). A finding of intercurrent death has various outcomes for both criminal and compensation law. Especially in deaths after traumatic injuries due to assault, investigation of medical malpractice claims should reveal the exact cause of death and other associated factors directly or indirectly affecting the death mechanism. Moreover, this investigation should be performed in cases of death after non-lethal traumatic injuries to reveal any mitigating factors for perpetrators.

Successful triage in the emergency room determines the severity of trauma, which directs the treatment carried out and the monitoring pathways used. Various types of scoring 
systems are utilized for this purpose. Calculation of a trauma score provides identification of the severity of trauma, prediction of the probability of survival, and evaluation of applied treatment protocols. In the calculation process, all injuries are identified, classified, and scored. ${ }^{[-4]}$ Frequently referenced scoring systems include the Abbreviated Injury Scale (AIS), the Injury Severity Score (ISS), and New Injury Severity Score (NISS). ${ }^{[1,4]}$

This study provides a new approach to evaluating medical malpractice claim cases, not only for forensic medicine specialists, but also for academics from all specialties who may be called by the courts to be an expert witness to assist with determining any responsibility of the physician in the cause of death.

In a case of trauma patient death after possible medical malpractice, the injuries that initially led the patient to go to the hospital should be described as either "lethal injury even if there was no malpractice" or "non-lethal injury if accurate treatment applied." It is obvious that this can be achieved by calculating trauma scores. In this way, the effect of faulty acts or omissions of physicians on the death of the patient can be determined.

\section{MATERIALS AND METHODS}

\section{Case Selection}

Cases were selected from the case archive of the General Committee of the Council of Forensic Medicine (GC of CFM) that were discussed and concluded between the years 2010 and 20I3. GC is a second-opinion board for discussing and concluding the reports with objection, and also is the supreme decision authority of the CFM. Therefore, the decisions of the GC are the final decisions of the council. All medical malpractice case files were searched retrospectively and evaluated. Only cases of trauma were selected for the study, regardless of the type of trauma.

\section{Data Collection}

For all cases included, the following records were retrieved: patient demographic data of age and sex, information about the incident (type of trauma), medical records of all health institutions involved including complete records of all injuries, medical specialties involved (general surgery, neurosurgery, etc.), diagnoses and treatment protocols (especially medical records of accused physicians collected separately); and results of ancillary tests and autopsy, if performed.

\section{Calculation of Injury Scores and Case Classification}

The calculation of the ISS and NISS was carried out retrospectively according to the "Abbreviated Injury Scale 2005, Update 2008" [5] with the findings of accused physicians examined separately as well as exact trauma scores calculated with the findings obtained at the last evaluation of the patient, or during autopsy. ISS and NISS of 15 or less was accepted as minor trauma (non-lethal injury if accurate treatment applied) and classed as Group I, ISS and NISS of 16 or more was considered major trauma (lethal injury even if there is no malpractice) and categorized as Group 2, and ISS and NISS of 75 was accepted as lethal injury even if accurate treatment applied and made up Group 3 for this study.

\section{RESULTS}

A total of 263 medical malpractice cases were discussed and concluded in the GC between 2010 and 2013, and of these, there were 120 cases of inpatient stay that ended with the death of the patient. There were 26 reports $(9.9 \%$ among overall medical malpractice cases and $21.7 \%$ among death cases) from this time period that met our selection criteria. One case was excluded due to the type of malpractice claimed: The physician was accused of "not administering tetanus vaccine after trauma." All calculations and evaluations of this study were performed using those 25 files. Twentyone patients (84\%) were men and 4 (16\%) were women, with an overall male-to-female ratio of $5.3: 1$. The mean age of the patients was $36.7 \pm 17.0$ years (range: $8-76$ years).

All cases involved I or more branches of surgery. In I I cases (44\%), injuries were related to general surgery, and next in frequency was neurosurgery, with 6 cases (24\%). Other surgical specialties involved were 4 cases (16\%) of cardiovascular surgery, 2 cases (8\%) of orthopedics, I case of pediatric surgery, and I of thoracic surgery. Thirteen cases (52\%) were admitted to the hospital due to a traffic accident, 4 cases (16\%) were due to sharp force injury, 2 cases (8\%) were due to occupational accident, 2 cases (8\%) were due to firearm-related injury, and the remainder were various other types of injury. The mean duration of hospitalization for each case was 2.4 \pm 3.4 days (range: $0-13$ days). Ten patients (40\%) died on the same day of the trauma, and 6 patients $(24 \%)$ died the next day.

In these 25 case files, 34 physicians were accused of medical malpractice. In 9 cases, 2 physicians were accused, while in 16 cases, only I physician was accused. Of the physicians, 20 (58.8\%) were specialists, II physicians (32.4\%) were general practitioners, and 3 physicians $(8.8 \%)$ were residents. Twenty-one (84\%) interventions that led to accusation of malpractice occurred in state hospitals, 3 (12\%) occurred in private hospitals, and I (4\%) occurred at a teaching hospital.

After the calculation of trauma scores, in 23 cases (92\%) exact ISS score of the patient was greater than 16 (lethal trauma) (Group 2), and in 2 cases (8\%) trauma score was less than 16 (minor trauma) (Group I). Fifteen of 23 patients (65.2\%) in Group 2 were evaluated as Group I in 20 the physicians' medical records. Three patients were evaluated as Group I by the first accused physician but evaluated as Group 2 by a second accused physician. 


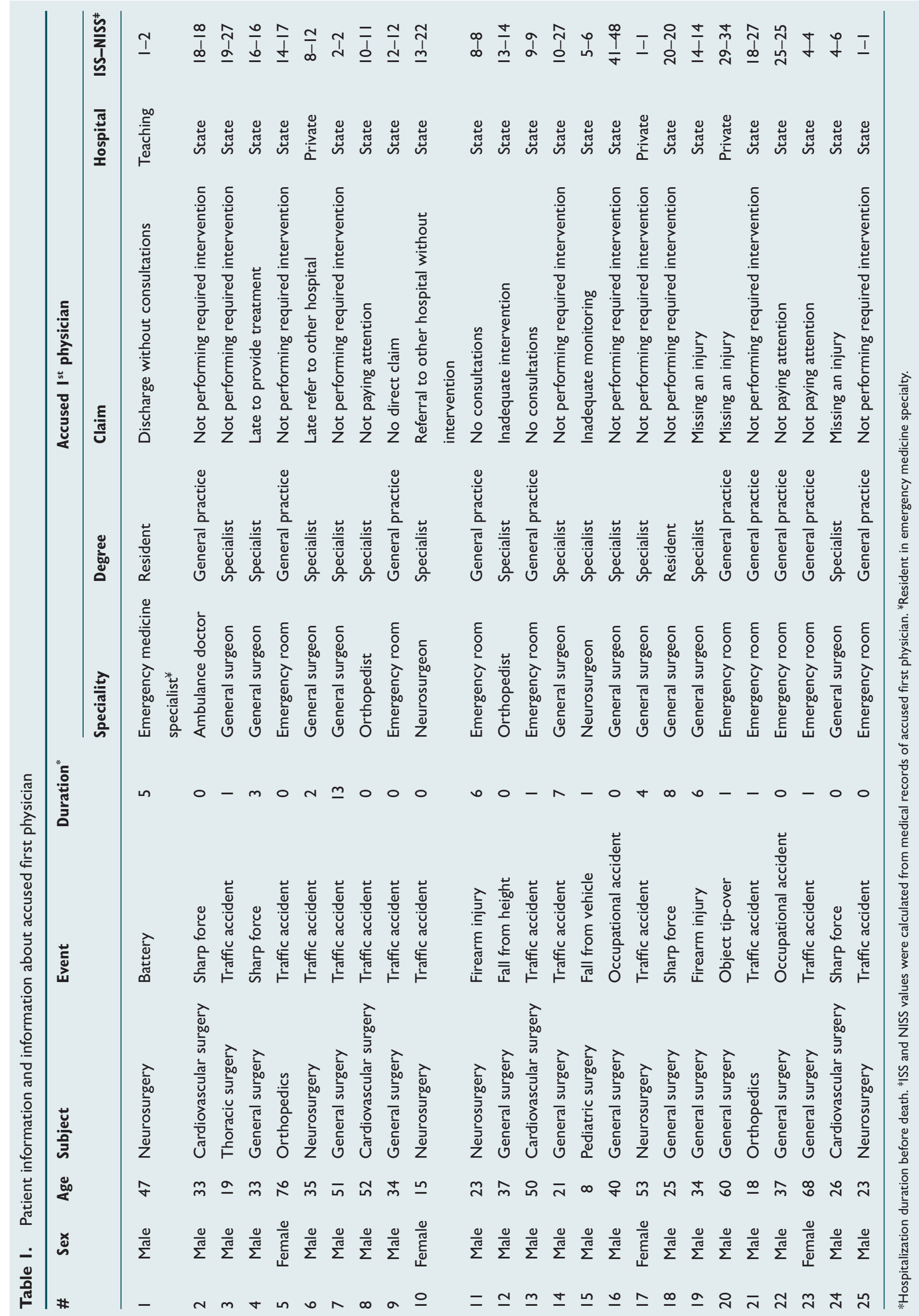




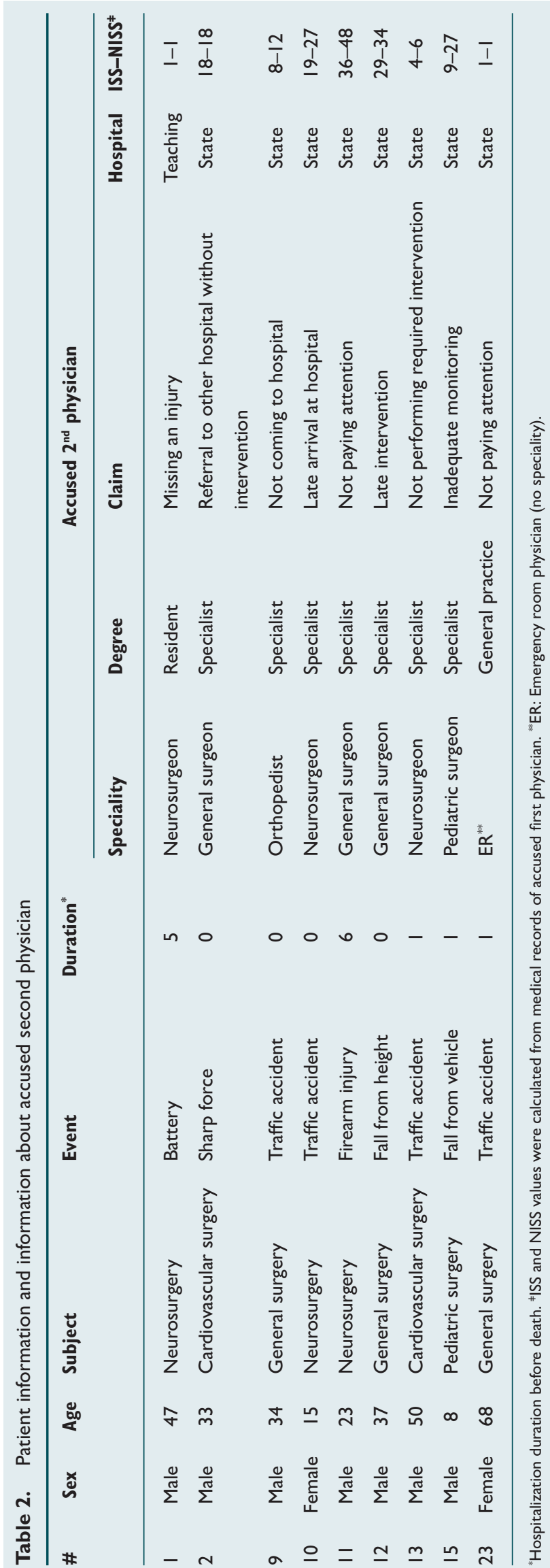

When claims were assessed with respect to the first physician, in 15 cases $(60 \%)$, the first physician was accused of "not performing the required intervention." In 3 cases, the physician was accused of "missing an injury," and in 3 cases, the physician was accused of "not having the required consultations." In 4 cases, physicians were accused of 4 different claims, such as "starting the treatment late," "late referral to higher level health center," "referral without any evaluation or intervention," and "no detailed claim." For the second physician, in 3 cases out of 9 (33.3\%), the physician was accused of "not performing the required intervention." In 2 cases, the physician was accused of "not paying attention," and in 2 cases, the physician was accused of "not coming or coming late to the hospital despite being called." In I case, the physician was accused of "missing an injury," and in I case the physician was accused of "referral to a higher level health center without having any consultations." All patient and accused physician data, as well as information about the interventions that resulted in claim of malpractice are presented in Tables I and 2.

In 12 of 25 cases (48\%), the GC concluded that the events constituted malpractice. In 4 cases, the first physician's intervention was found to be proper, but the second physician had committed malpractice. In 2 cases, it was concluded that both physicians' interventions were acts of malpractice. In the remaining 6 cases, only I physician was accused.

When the results of the GC reports were evaluated, the severity of the trauma was mentioned in only 5 reports. In 4 of these, in which the ISS was calculated to be greater I6, it

Table 3. GC conclusions and number of physician interventions according to accuracy of calculated trauma score group

\begin{tabular}{|c|c|c|c|}
\hline GC conclusion & $\begin{array}{c}\text { Accurate }^{\ddagger} \\
\text { group } \\
\text { n (\%) }\end{array}$ & $\begin{array}{c}\text { Non-accurate } \\
\text { group } \\
\mathbf{n}(\%)\end{array}$ & $\mathbf{p}^{*}$ \\
\hline \multicolumn{4}{|l|}{ ISS value } \\
\hline Malpractice & $6(42.9)$ & $8(40)$ & 0.868 \\
\hline No Malpractice & $8(57.1)$ & $12(60)$ & \\
\hline Total & $14(100)$ & $20(100)$ & \\
\hline \multicolumn{4}{|l|}{ NISS value } \\
\hline Malpractice & $7(43.8)$ & 7 (38.9) & 0.774 \\
\hline No Malpractice & $9(56.2)$ & II (6I.I) & \\
\hline Total & $16(100)$ & $18(100)$ & \\
\hline
\end{tabular}

†Trauma score group evaluated as "Accurate", if the trauma score group of the findings of the physicians was the same as the correct trauma score group. 'Trauma score group evaluated as "Non-accurate", if the trauma score group of the findings of the physicians was the same as the correct trauma score group. "Pearson chi-square. GC: General Committee; ISS: Injury Severity Score; NISS: New Injury Severity Score. 
was concluded that survival was not certain even in the case of correct treatment, and in I case, in which the ISS was equal to 16, the conclusion was "patient may survive with accurate treatment." In the remaining cases, no conclusion was reached about the severity of the trauma. The conclusions reached by the GC decisions and the ISS values calculated are presented in Tables 3, 4 and 5.

Calculated NISS results were quite similar in classification. In I case, the correct ISS calculated was 14, and the NISS was 17 (moved into Group 2), but the score was also elevated from 14 to 17 according to the first physician's records. In another case, the correct NISS was calculated as 75, while the ISS was 45 (moved into Group 3), but the first physician's findings resulted in NISS and ISS of 25. In the other cases, groups did not change according to ISS or NISS value.

\section{DISCUSSION}

Injuries are an important public health concern. According to the 2014 report "Injuries and Violence: the Facts" from the World Health Organization (WHO), traffic accidents and falls are high on the lists of leading causes of traumatic deaths. In 2012 , traffic accidents were ranked $9^{\text {th }}$ and falls were ranked $2{ }^{\text {st }}$ on the list of leading causes of death, with ischemic heart diseases ranked at the top. According to a WHO prediction for 2030, deaths due to traffic accidents are expected to rise to 7 th place, and falls to rise to the $17^{\text {th }}$ rank. ${ }^{[6]}$

In a trauma patient, one of the major factors affecting mortality is the severity of the trauma. ${ }^{[4,7]}$ Various scoring systems are utilized to evaluate injuries with an objective approach. Some of these scoring systems are anatomical, and some are based on physiological status. The most widely used

Table 4. ISS and NISS values and malpractice decisions of the GC

\begin{tabular}{|c|c|c|c|c|c|c|c|c|c|c|}
\hline \multirow[t]{2}{*}{ \# } & \multicolumn{2}{|c|}{$\begin{array}{l}\text { Accused Ist } \\
\text { physician }\end{array}$} & \multicolumn{2}{|c|}{$\begin{array}{l}\text { Accused } 2^{\text {nd }} \\
\text { physician }\end{array}$} & \multicolumn{2}{|c|}{$\begin{array}{c}\text { Last evaluation } \\
\text { before death }\end{array}$} & \multicolumn{2}{|c|}{ Postmortem $^{a}$} & \multirow[t]{2}{*}{$\begin{array}{c}\text { Decision for |st } \\
\text { physician }\end{array}$} & \multirow[t]{2}{*}{$\begin{array}{l}\text { Decision for } \\
2^{\text {nd }} \text { physician }\end{array}$} \\
\hline & ISS & NISS & ISS & NISS & ISS & NISS & ISS & NISS & & \\
\hline I & I & 2 & 1 & I & 9 & II & 16 & 26 & Malpractice & Malpractice \\
\hline 2 & 18 & 18 & 18 & 18 & 18 & 18 & - & - & Malpractice & Malpractice \\
\hline 3 & 19 & 27 & - & - & 27 & 27 & 27 & 27 & Malpractice & - \\
\hline 4 & 16 & 16 & - & - & 16 & 16 & 16 & 16 & Malpractice & - \\
\hline 5 & 14 & 17 & - & - & 14 & 17 & 14 & 17 & No malpractice & - \\
\hline 6 & 8 & 12 & - & - & 29 & 38 & 29 & 38 & No malpractice & - \\
\hline 7 & 2 & 2 & - & - & 26 & 27 & 26 & 27 & No malpractice & - \\
\hline 8 & 10 & II & - & - & 10 & II & 38 & 43 & Malpractice & - \\
\hline 9 & 12 & 12 & 8 & 12 & 12 & 12 & 29 & 29 & No malpractice & Malpractice \\
\hline 10 & 13 & 22 & 19 & 27 & 27 & 27 & - & - & No malpractice & No malpractice \\
\hline 11 & 8 & 8 & 36 & 48 & 36 & 48 & 41 & 48 & No malpractice & Malpractice \\
\hline 12 & 13 & 14 & 29 & 34 & 25 & 34 & - & - & No malpractice & No malpractice \\
\hline 13 & 9 & 9 & 4 & 6 & 4 & 6 & 24 & 36 & No malpractice & No malpractice \\
\hline 14 & 10 & 27 & - & - & 27 & 27 & - & - & No malpractice & - \\
\hline 15 & 5 & 6 & 9 & 27 & 5 & 6 & 34 & 34 & No malpractice & Malpractice \\
\hline 16 & 41 & 48 & - & - & 41 & 48 & 36 & 48 & No malpractice & - \\
\hline 17 & I & I & - & - & 13 & 13 & 25 & 25 & No malpractice & - \\
\hline 18 & 20 & 20 & - & - & 25 & 25 & 29 & 48 & Malpractice & - \\
\hline 19 & 14 & 14 & - & - & 14 & 14 & 14 & 14 & No malpractice & - \\
\hline 20 & 29 & 34 & - & - & 45 & 50 & - & - & No malpractice & - \\
\hline 21 & 18 & 27 & - & - & 22 & 27 & - & - & No malpractice & - \\
\hline 22 & 25 & 25 & - & - & 25 & 34 & 45 & 75 & No malpractice & - \\
\hline 23 & 4 & 4 & 1 & I & I & I & 24 & 36 & No malpractice & Malpractice \\
\hline 24 & 4 & 6 & - & - & I & 3 & 17 & 33 & Malpractice & - \\
\hline 25 & I & 1 & - & - & 20 & 21 & - & - & Malpractice & - \\
\hline
\end{tabular}

aEmpty cell: No autopsy performed. ISS: Injury Severity Score; NISS: New Injury Severity Score; GC: General Committee. 


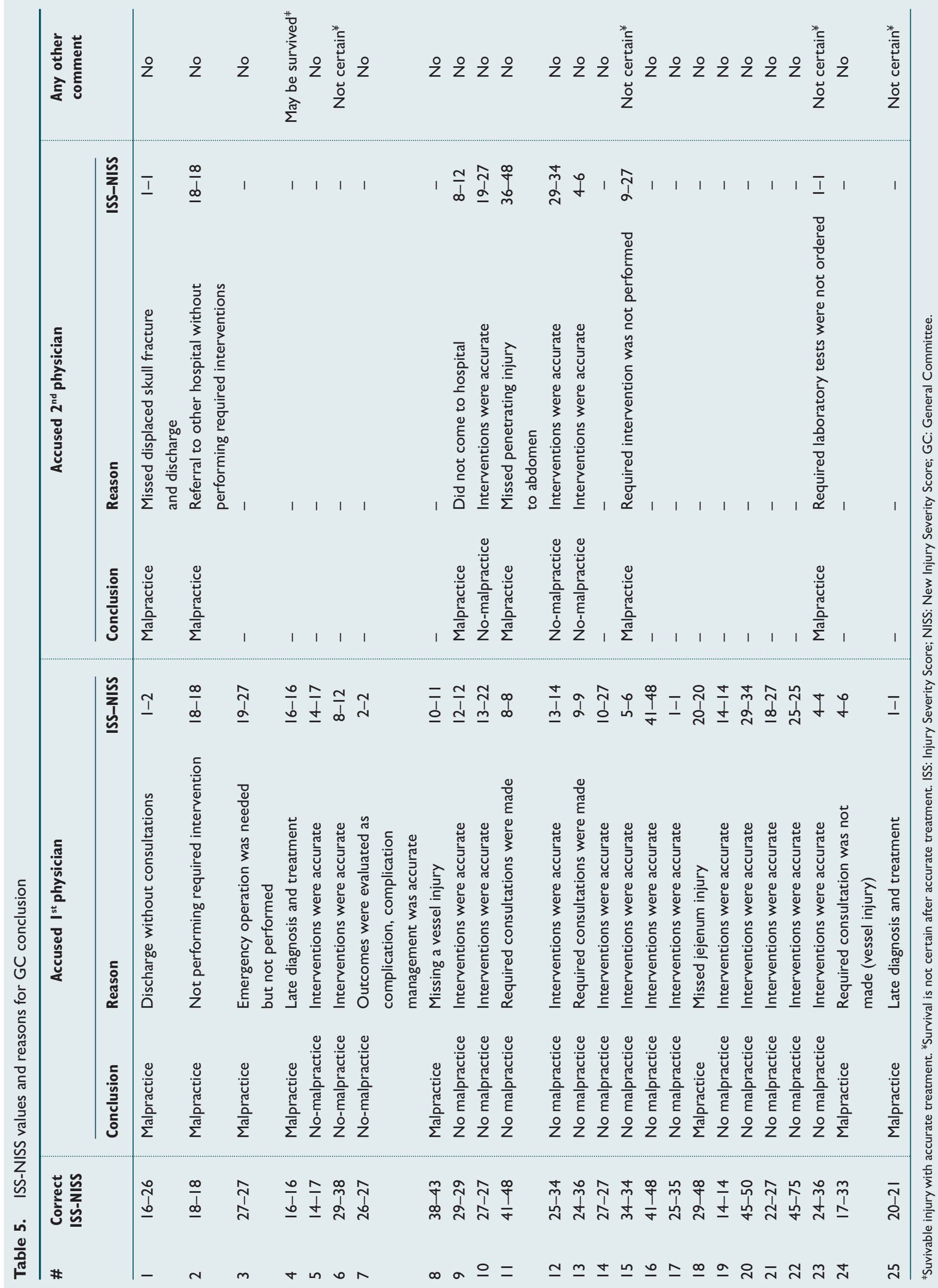


scoring systems are the AIS, the ISS, the NISS, the Glasgow Coma Scale (GCS), the Trauma and Injury and Severity Score (TRISS), the Revised Trauma Score (RTS), and A Severity Characterization of Trauma (ASCOT). ${ }^{[5,8-12]}$ Trauma scoring systems are also used during autopsy to evaluate the effect of the trauma on cause of death. There are numerous studies comparing postmortem and antemortem trauma scores at autopsy. ${ }^{[2,3,13-18]}$

In the emergency room, some injuries may be overlooked during interventions, and this may be the source of a malpractice claim. Among all medical specialties, specialties that deal with trauma carry an increased malpractice risk. [19] At the moment of admission to a health center, one of the most important steps is to determine the severity of the trauma and perform the appropriate triage on trauma patients.

When evaluating a medical malpractice case, the following criteria should be considered: I) approaches taken by the physicians; 2) whether or not the physicians provided the standard required care and attention; 3) whether informed consent was obtained; 4) whether the physician's order required ancillary tests and whether it required consultations; 5) whether the correct diagnosis was made and whether the physician(s) ordered the correct treatment and surgical protocol; 6) whether the follow-up and monitoring were accurate; 7$)$ whether the outcome was an expected complication, or an adverse effect; and 8) if the outcome was a complication, whether it was diagnosed in the early period and whether the complication management was protocol-correct. ${ }^{\text {[9-22] }}$ Weiland et al. ${ }^{[2]}$ added some other factors affecting malpractice risk: hospital designation, physician training, and management of injured patients.

Determining the severity of the trauma may have a key role in concluding the malpractice claims of trauma patients concerning two points: I) Could the physician have arrived at the correct diagnosis without missing any injury? and 2) Could the outcome have changed if there was no malpractice (if the correct treatment/surgery were administered)?

In the present study, according to the trauma scores calculated from the accused physicians' medical records, $60 \%$ of the ISS values ( $n=15$; correct group was Group 2 while the first physician evaluated patient as Group I), and $60 \%$ of the NISS $(n=15$; in I case, correct group was Group 3, and in 14 cases, accurate group was Group 2, but the first physician evaluated it as I level less) were evaluated by the physician as I group below the true score. For the second physician, $55.6 \%$ of the ISS $(n=5)$ and $44.4 \%$ of the NISS $(n=4)$ were evaluated as I group below the correct score (Group 2 to I). Of course, injuries missed on the first evaluation don't always mean that the interventions that followed were not accurate. In the end, only the interventions of 4 out of 15 physicians (26.7\%) (first physician evaluated the patient as I group below the correct group) were concluded to be malpractice. The reasons for those conclusions were I) discharging the patient without having the required consultations, 2) missing a vessel injury, 3) not having required consultations, and 4) being late to initiate the treatment. In addition, the interventions of 4 physicians were judged to be malpractice although the first physician's evaluation of trauma severity was accurately labeled with the correct group. The reasons for these conclusions were I) not performing the required intervention on the scene (ambulance doctor), 2) not performing emergency surgery despite its necessity, 3) late diagnosis and treatment, and 4) missing a jejunum injury. These results indicated that determination of injury severity is important, but evaluation of a medical malpractice case should not be based solely on trauma scores.

With regard to the accuracy of the trauma score groups as calculated from the medical records of accused physicians, there was no statistically significant correlation between the accuracy and the malpractice conclusion of the GC for either the ISS or the NISS $(p>0.05)$. This demonstrates that while discussing and reaching a conclusion about the responsibility of a physician in a malpractice case, the trauma score is not enough information to evaluate the whole case. Other decisive factors should also be considered. When writing the report, trauma severity should be stated by an expert witness classified in the following 3 categories: I) non-lethal injury, if accurate treatment is applied; 2) lethal injury although there is no malpractice; 3 ) lethal injury even if accurate treatment is applied. This will allow the expert witness to determine the level of responsibility of any perpetrator and the physician in the patient's death. These conclusions may assist the judges to make decisions on guilt ratios of a perpetrator and the physician in a death with respect to both criminal and compensation law.

Another point that should be discussed in medical malpractice cases is the need for autopsy. In the present study, autopsy was performed in 18 cases (72\%), and of these, in 8 cases (44.4\%) the correct ISS and NISS group was elevated according to the autopsy findings. In addition to the important role of autopsy findings in improving trauma management and quality assurance, ${ }^{[23]}$ autopsy is mandatory in the investigation of malpractice to reveal whether or not an injury was missed. The purpose of an autopsy is not just to accuse the physician; autopsy findings may justify the actions of a defendant physician and their responsibility in the death may be reduced. Autopsy may reveal unrecognized diseases or missed injuries, or may confirm the clinical diagnosis of accused physicians. [24] In I case in this study, NISS value was calculated as 75 (while the physician's score was 25) and the severity was interpreted as "lethal injury even if accurate treatment applied." This means "the outcome would not change even if there was no malpractice." In this case GC decided that the "required interventions were performed, required consultations were held, and there was no malpractice," but did not mention the severity of trauma, probably because it was concluded that there was no malpractice. In the study of Enderson et al., in 
which missing injuries were evaluated in a university hospital medical center, musculoskeletal injuries were most frequently missed, and they concluded that closed-head injuries and alcohol or drug influence on the patient were the most frequent contributing factors to missing an injury. ${ }^{[25]}$ Weiland et al. ${ }^{[2]]}$ also reported similar missed injury pattern, with overlooked fractures ranked first, followed by head injuries and thoracic or abdominal injuries. All missed injuries have an effect on the trauma scores of a patient on admission. A missed injury detected during autopsy may assist an expert witness to form a conclusion about the possibility of malpractice.

In conclusion, a multidirectional approach should be taken in a malpractice case. Evaluating the initial diagnosis is the one step. Comparing the initial diagnosis and the final diagnosis with the ISS and NISS calculated using the initial medical records and autopsy findings may aid in establishing an accurate conclusion, especially with respect to missed injuries.

\section{Financial Support}

The authors declare that they received no financial support for this study.

\section{Conflict of interest: None declared.}

\section{REFERENCES}

1. Copes WS, Lawnick M, Champion HR, Sacco WJ. A comparison of Abbreviated Injury Scale 1980 and 1985 versions. J Trauma Acute Care Surg 1988;28:78-86. [CrossRef]

2. Toka H, Karbeyaz K, Gündüz T, Balcı Y. Could postmortem ISS and NISS points sign preventable deaths? The Bulletin of Legal Medicine 2010;15:4-12. [CrossRef]

3. İnce $\mathrm{CH}$, İnce $\mathrm{N}$, Taviloğlu $\mathrm{K}$, Güloğlu R. A different approach to trauma scoring. Ulus Travma Acil Cerrahi Derg 2006;12:195-200.

4. Orhon R, Eren ŞH, Karadayı Ş, Korkmaz İ, Coşkun A, Eren M, et al. Comparison of trauma scores for predicting mortality and morbidity on trauma patients. Ulus Travma Acil Cerrahi Derg 2014;20:258-64.

6. Injuries and Violence. The Facts 2014. Geneva, Switzerland: World Health Organization; 2014. Available from: http://apps.who.int/iris/ bitstream/10665/149798/1/9789241508018_eng.pdf?ua=18ua=1.

7. Özgüç H, Kaya E, Korun N. Factors affecting outcome in the resuscitation of trauma. Ulus Travma Acil Cerrahi Derg 1995;1:51-8.

8. Guidelines for Trauma Quality Improvement Programmes. Geneva, Switzerland: World Health Organization; 2009. Available from: http://apps. who.int/iris/bitstream/10665/44061/1/9789241597746_eng.pdf.
9. Copes WS, Champion HR, Sacco WJ, Lawnick MM, Gann DS, Gennarelli T, et al. Progress in characterizing anatomic injury.J Trauma Acute Care Surg 1990;30:1200-7. [CrossRef]

10. Günay Y. Trauma scoring and forensic medicine. The Bulletin of Legal Medicine 1999;4:65-73. [CrossRef]

11. Baker SP, o'Neill B, Haddon Jr W, Long WB. The injury severity score: a method for describing patients with multiple injuries and evaluating emergency care. J Trauma Acute Care Surg 1974;14:187-96. [CrossRef]

12. Eid HO, Abu-Zidan FM. New Injury Severity Score is a better predictor of mortality for blunt trauma patients than the Injury Severity Score. World J Surg 2014;39:165-71. [CrossRef]

13. Elçi Ç. Comparison of antemortem and postmortem trauma scores [Unpublished Thesis]. İstanbul, Turkey: The Council of Forensic Medicine, Ministry of Justice 2013.

14. Subedi N, Yadav B, Jha S. Application of Abbreviated Injury Scale and Injury Severity Score in fatal cases with abdominopelvic injuries. Am J Forensic Med Pathol 2014;35:275-7. [CrossRef]

15. Adams VI, Carrubba C. The Abbreviated Injury Scale: application to autopsy data. Am J Forensic Med Pathol 1998;19:246-51. [CrossRef]

16. Riddick L, Long WB, Copes WS, Dove DM, Sacco WJ. Automated coding of injuries from autopsy reports. Am J Forensic Med Pathol 1998;19:269-74. [CrossRef]

17. Eryılmaz M, Durusu M, Cantürk G, Menteş MÖ, Özer MT. Role of anatomic and physiologic trauma scoring systems in forensic cases. Ulus Travma Acil Cerrahi Derg 2009;15:285-92.

18. Sharma BR. The injury scale--a valuable tool for forensic documentation of trauma. J Clin Forensic Med 2005;12:21-8. [CrossRef]

19. McGwin GJ, Wilson SL, Bailes J, Pritchett P, Rue LWI. Malpractice Risk: Trauma Care Versus Other Surgical and Medical Specialties. J Trauma Acute Care Surg 2008;64:607-13. [CrossRef]

20. Yazıcı YA, Şen H, Aliustaoğlu S, Sezer Y, İnce CH. Evaluation of the medical malpractice cases concluded in the General Assembly of Council of Forensic Medicine. Ulus Travma Acil Cerrahi Derg 2015;21:204-8.

21. Weiland DE, Malone JM, Krebs R, Ward J. Trauma malpractice claims related to trauma level designation. Am J Surg 1989;158:553-6. [CrossRef]

22. Brennan TA, Sox CM, Burstin HR. Relation between Negligent Adverse Events and the Outcomes of Medical-Malpractice Litigation. N Engl J Med 1996;335:1963-7. [CrossRef]

23. Rautji R, Bhardwaj D, Dogra T. The Abbreviated Injury Scale and its correlation with preventable traumatic accidental deaths: a study from South Delhi. Med Sci Law 2006;46:157-65. [CrossRef]

24. Bove KE, Iery $\mathrm{C}$. The role of the autopsy in medical malpractice cases, I: A review of 99 appeals court decisions. Arch Pathol Lab Med 2002;126:1023-31.

25. Enderson BL, Reath DB, Meadors J, Dallas W, Deboo JM, Maull KI. The tertiary trauma survey: A prospective study of missed injury. J Trauma Acute Care Surg 1990;30:666-70. [CrossRef] 


\section{ORİJINAL ÇALIŞMA - ÖZET}

\section{Tıbbi uygulama hatası iddiası olan travmatik ölümlerde hekim sorumluluğunun belirlenmesinde travma skoru sistemlerinin kullanılması}

\section{Dr. Murat Nihat Arslan, ${ }^{1}$ Dr. Çisem Kertmen, ${ }^{2}$ Dr. Deniz Oğuzhan Melez, ${ }^{1}$ Dr. Durmuş Evcüman, ${ }^{3}$ Dr. Yalçın Büyük ${ }^{4}$}

${ }^{1}$ Adli Tıp Kurumu, Morg İhtisas Dairesi, İstanbul

${ }^{2}$ Adli Tıp Kurumu, Düzce Adli Tıp Şube Müdürlüğü, Düzce

${ }^{3}$ Adli Tıp Kurumu, Çanakkale Adli Tıp Şube Müdürlüğü, Çanakkale

${ }^{4}$ Adli Tıp Kurumu, İstanbul

AMAÇ: Travmatik ölümler Dünya Sağıı Örgütü’nün başlıca ölüm sebepleri listesinde en üst sıralarda yer almaktadır ve bu ölümlerde mortaliteyi en fazla etkileyen faktörlerden birisi travmanın şiddetidir. Travma hastalarında tıbbi girişimler sırasında kimi yaralanmalar atlanabilmekte ve bu durum tıbbi uygulama hatası iddialarının doğmasına neden olabilmektedir. Bu çalışmanın amacı, travma skorlama sistemlerinin sağlayacağı yararı ortaya çıkarak tıbbi uygulama hatası iddiası olan olguların değerlendirilmesine yeni bir bakış açısı getirmektir.

GEREÇ VE YÖNTEM: Olgulara Adli Tıp Kurumu Genel Kurulu'nda 20।0-20।3 yılları arasında görüşülerek karara bağlanmış dosyalar taranarak ulaşıldı. Tıbbi uygulama hatası olan hekimin tıbbi kayıtları, otopsi ya da son klinik değerlendirme bulguları göz önüne alınarak her birisi için ayrı ayrı yaralanma ağıllık soruları hesaplanarak karşış̧̧ııııldı.

BULGULAR: 20।0-2013 yılları arasında 263 tıbbi uygulama hatası iddiası dosyası tartışılarak karara bağlanmıştır. Bunlardan 25’i hastanın ölümüyle sonuçlanmış olgulardır. Bu 25 olguda 34 hekim hakkında tıbbi uygulama hatası ile iddiası ortaya atısmıştır. Kurul I2 olguda I4 hekimin tıbbi uygulama hatası olduğu yönünde karar vermiştir. Hakkında iddia olan hekimin tuttuğu tıbbi kayıtlarda saptayabilmiş olduğu travma bulguları ile otopsi ya da son klinik değerlendirmede saptanan tüm bulgulara ait Yaralanma Ağılık Skoru ve Yeni-Yaralanma Ağılık Skoru hesaplanarak atlanmış ya da gözden kaçırımış yaralanmaların ölüm üzerindeki etkisi ortaya konabilecektir.

TARTIŞMA: Tıbbi uygulama hatası iddiası bulunan olgularda travma skorlarının hesaplanması tüm dallardan tıbbi bilirkişilikle görevlendirilmiş uzmanlara ve ayrıca hakimlere, atlanmış ya da gözden kaçırımış yaralanmaların etkilerinin ortaya çıkarılmasında ve hekimin sorumluluğunun yorumlanmasında ve olgunun uygulama hatası olmasaydı yaşayabilme ihtimalinin belirlenmesinde yardımcı olacaktır. Tek başına karar verdirici bir ölçüt olarak değil diğer tüm bulguları destekleyici bir araç olarak kullanılabilecektir.

Anahtar sözcükler: Gözden kaçırılmış yaralanmalar; tıbbi uygulama hatası; travmatik ölümler; Yaralanma Ağıılık Skoru; Yeni-Yaralanma Ağırlık Skoru.

Ulus Travma Acil Cerrahi Derg 2017;23(4):328-336 doi: 10.5505/tjtes.2016.50540 